\title{
Role of structural modifications of montmorillonite, electrical properties effect, physical behavior of nanocomposite proton conducting membranes for direct methanol fuel cell applications
}

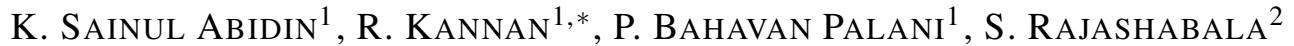 \\ ${ }^{1}$ Department of Physics, University College of Engineering, Anna University, Dindigul-624622, Tamil Nadu, India \\ ${ }^{2}$ School of Physics, Madurai Kamaraj University, Madurai-625021, Tamil Nadu, India
}

\begin{abstract}
Proton exchange membranes have been synthesized from polyimide (PI) doped with different contents of montmorillonite (MMT) which was obtained by solution casting technique. The enhancement of conductivity was achieved through modification with the MMT. Prepared membranes were systematically characterized in terms of ion exchange capacity, water uptake, methanol uptake, swelling behavior and proton conductivity. Fourier transform infrared spectroscopy and X-ray diffraction measurements were used to confirm the structures of the PI/MMT composite electrolyte membranes. SEM surface morphological images of the composite membranes showed that the MMT nanoclay particles were dispersed uniformly within the membrane what was also reflected in XRD results which indicated a good compatibility of MMT particles with the polymer complex. The TGA spectra showed that the thermal stability of the membrane was reduced by adding MMT into the polymer network. The prepared membrane with $10 \mathrm{wt} . \%$ of modified MMT exhibited the highest proton conductivity value of $7.06 \times 10^{-2} \mathrm{~S} \cdot \mathrm{cm}-1$ at $70{ }^{\circ} \mathrm{C}$. These results imply the potential application of the PI/MMT composite membranes as improved PEMs for DMFC applications.
\end{abstract}

Keywords: proton exchange membrane; polyimide; proton conductivity; montmorillonite; direct methanol fuel cell

\section{Introduction}

Fuel cells (FCs) play an immense role in the development of sustainable energy technologies that alleviate global warming and reduce the dependence on fossil fuels [1]. They offer many advantages such as high energy density, high efficiency, quiet operation, and environmental friendliness. Among various kinds of fuel cells, direct methanol fuel cells (DMFCs) are very convenient for portable electronic devices and transportation applications as they exhibit high energy density at low operating temperatures and are simple to handle liquid (methanol) fuel. The proton exchange membrane (PEM) is a crucial component in DMFC which works as a barrier to reactant mixtures of anode and cathode. It is responsible for proton transport from anode to cathode during the cell

*E-mail: rksrsrk@gmail.com operation. It also has high oxidative and hydrolytic stability, good mechanical toughness in both dry and hydrated states, and low operating costs in the actual fuel cell environment $[2,3]$. Nafion is the most advanced commercially available perfluorosulfonic acid membrane which exhibits high proton conductivity and excellent chemical stability nevertheless high methanol permeation [4]. Fuel diffusion from the anode to the cathode-fed cell can decrease the cell output voltage, due to a mixed potential at the cathode that decreases the fuel efficiency of the device. Moreover, high cost, synthetic difficulties and inefficiency at high temperature are some drawbacks of Nafion [5]. These drawbacks have paved the way for the extensive research on developing proton exchange membrane [6]. Therefore, it is strongly desirable to develop new PEM materials with reduced cost and high performance.

Polyimides (PI) have been investigated as a potential PEM material by several researchers 
[7-11]. The polyimides have variety of chemical structures and can be modified chemically at very low cost. Aromatic polyimides, due to their salient features like high thermo-mechanical stability, thermo-oxidative stability and superior chemical resistance, are viewed as suitable PEM material to work with in this difficult fuel cell environment [10, 12-14]. Also the polyimides have shown promising characteristics in terms of their low methanol crossover and affordable conductivity $[9,10,15,16]$. Nguyen et al. [17] reported that, the composite membranes of polyimide with sulfonated poly (ether sulfone) have excellent properties compared to Nafion membrane, such as lower dimensional change, higher mechanical strength and proton conductivity, and 20 times lower methanol crossover. Besides, cost reduction is possible due to less expensive ingredients of the polyimide and the simple procedure of the polymerization [8, 18]. By selecting apt nanoscopic additives, dispersion of inorganic filler in the polymeric matrix has been proposed as an effective method to improve the membrane efficiency. Among others, exfoliation of montmorillonite nanoclay in the polymeric matrices could lead to better methanol barrier properties as well as improved thermomechanical properties [19].

The prime objective of this work is the synthesis and characterization of membranes comprising polyimide with modified and unmodified montmorillonite (MMT). The capability of the prepared membrane for DMFC applications has been considered by assessing their IEC, water uptake, methanol uptake and proton conductivity. The results have been summarized in the results and discussion sections.

\section{Experimental}

\subsection{Materials and membrane preparation}

PI (Otto Chemie), MMT K10 (Himedia), and ion exchange resin $(\mathrm{CDH})$ were the chemicals (AR grade) used in this study. The PI/MMT composite membranes were prepared using solution casting technique. The montmorillonite used for membrane preparation was modified to its protonated form from the $\mathrm{Na}^{+} \mathrm{MMT}$. The experimental procedure to prepare the modified MMT was reported in our previous work [20]. The scheme of synthesis $\mathrm{H}^{+}$MMT from $\mathrm{Na}^{+}$MMT is shown in Fig. 1. An appropriate amount of PI was dissolved in $\mathrm{m}$-Cresol solvent at a constant rate of stirring $(500 \mathrm{rpm})$ at $100{ }^{\circ} \mathrm{C}$ for 6 hours. Then, the prepared polymeric solution with MMT (unmodified/modified) was stirred at room temperature for 1 hour until MMT was dispersed in the polymeric system. Finally, the resultant composite solution was introduced into the ultrasonic bath for about half an hour to obtain a uniform dispersion of MMT. The homogeneous solution was poured into a Petri dish and kept at room temperature for complete removal of the solvent. After that, the dried composite membrane was peeled off from the Petri dish. We prepared nine samples of the composite electrolyte membranes for their systematic investigations. The details of chemical compositions and sample codes are listed in Table 1 . To remove contaminated particles, the membranes were washed several times with deionized water then dried in a hot air oven at $120{ }^{\circ} \mathrm{C}$ for 12 hours and $80^{\circ} \mathrm{C}$ for 12 hours for improving the mechanical stability of prepared membranes. Thicknesses of all the prepared composite membranes were found in the range of $0.4 \mathrm{~mm}$ to $0.7 \mathrm{~mm}$ [21].

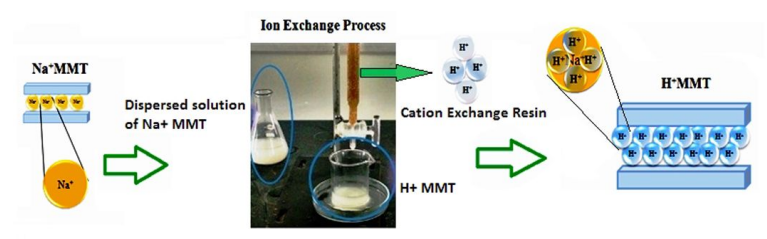

Fig. 1. Schematic representation of synthesis of $\mathrm{H}^{+}$MMT.

\subsection{Membrane characterization}

Fourier transform infrared (FT-IR) spectra were recorded using a Bruker spectrometer, between of $4000 \mathrm{~cm}^{-1}$ to $400 \mathrm{~cm}^{-1}$. The X-ray diffraction (XRD) measurements were performed from $10^{\circ}$ to $80^{\circ}$ on a PANalytical $X^{\prime}$ Pert diffractometer with $\mathrm{CuK} \alpha$ radiation $(40 \mathrm{kV}, 30 \mathrm{~mA})$. The morphology of surfaces of prepared membranes was analyzed 
Table 1. Sample codes and chemical composition of the composite electrolyte membranes.

\begin{tabular}{cccc}
\hline Sl. No. & Sample code & \multicolumn{2}{c}{ Composition [wt.\%] } \\
\hline \hline 1 & P0 & PI:Na ${ }^{+}$MMT & $100: 0$ \\
2 & P1 & PI:Na ${ }^{+}$MMT & $95: 05$ \\
3 & P2 & PI:Na ${ }^{+}$MMT & $90: 10$ \\
4 & P3 & PI:Na ${ }^{+}$MMT & $85: 15$ \\
5 & P4 & PI:Na MMT & $80: 20$ \\
6 & P5 & PI: $\mathrm{H}^{+}$MMT & $95: 05$ \\
7 & P6 & PI: $\mathrm{H}^{+}$MMT & $90: 10$ \\
8 & P7 & PI: $\mathrm{H}^{+}$MMT & $85: 15$ \\
9 & P8 & PI: $\mathrm{H}^{+}$MMT & $80: 20$ \\
\hline
\end{tabular}

using SEM (Quanta 200, FEI Company). The thermal stability of the membranes was analyzed by thermogravimetric analysis (TGA, 209 F1). Scans from $30{ }^{\circ} \mathrm{C}$ to $600{ }^{\circ} \mathrm{C}$ were performed at a heating rate of $10^{\circ} \mathrm{C} / \mathrm{min}$ in flowing nitrogen.

The composite membrane samples were dried in a hot air oven at $100{ }^{\circ} \mathrm{C}$ for 6 hours and weighted before water uptake, methanol uptake and dimensional swelling measurements. The samples were immersed in distilled water and methanol solution for 24 hours for measuring water and methanol uptake respectively $[22,23]$. The following equations were applied for calculating water and methanol uptake values:

$$
\begin{gathered}
\text { Water uptake }(\%)=\frac{W_{w e t}-W_{d r y}}{W_{d r y}} \times 100 \% \\
\text { Swelling }(\%)=\sqrt{\frac{A_{w e t}-A_{d r y}}{A_{d r y}}} \times 100 \%
\end{gathered}
$$

where $\mathrm{W}_{\text {wet }}$ is the weight of wet membranes and $\mathrm{W}_{\mathrm{dry}}$ is the weight of dried membranes; Awet is the area of wet membranes and Adry is the area of dried membranes.

The ion exchange capacity of membranes was determined by the back-titration method [5, 22]. The membranes in acid form were converted to sodium forms by immersing them in $1 \mathrm{M} \mathrm{NaCl}$ solution for 24 hours so as to exchange the $\mathrm{H}^{+}$ ions with $\mathrm{Na}^{+}$ions. The exchanged $\mathrm{H}^{+}$ions within the solution were titrated with $0.1 \mathrm{M} \mathrm{NaOH}$ solution with phenolphthalein as an indicator. The membranes ion exchange capacities were calculated from the titration data by the following equation:

$$
I E C=\frac{V_{\mathrm{NaOH}} \times C_{\mathrm{NaOH}}}{W_{d r y}}
$$

where $\mathrm{V}_{\mathrm{NaOH}}$ is the volume of $\mathrm{NaOH}$ solution and $\mathrm{C}_{\mathrm{NaOH}}$ is the concentration of $\mathrm{NaOH}$ solution. The membrane proton conductivity measurements were made in form of Nyquist plots using $\mathrm{CH}$ Instruments 600D series electrochemical analyzer with the applied amplitude of $10 \mathrm{mV}$ from $1 \mathrm{KHz}$ to $10 \mathrm{MHz}$. The conductivity values were calculated using the following equation:

$$
\sigma=\frac{l}{R D W}
$$

where $\sigma$ is proton conductivity in $\mathrm{S} \cdot \mathrm{cm}^{-1}, 1$ is the distance between the two reference electrodes, $\mathrm{R}$ is the measured value of membrane bulk resistance, while $\mathrm{D}$ and $\mathrm{W}$ are the thickness and width of the membrane sample at the ambient conditions, respectively [24].

The Arrhenius relation represents the temperature dependence of the rate constant for an elementary chemical reaction $[25,26]$. Arrhenius activation energy was calculated from the slope (gradient) of the linear plot of $\log \sigma$ against 1000/T.

$$
\sigma=A \exp \left(-\frac{E a}{R T}\right)
$$


where $\sigma, \mathrm{A}, \mathrm{E}_{\mathrm{a}}, \mathrm{R}$, and $\mathrm{T}$ denote the proton conductivity, frequency factor, activation energy for proton conduction, gas constant, and absolute temperature, respectively.

\section{Results and discussions}

\subsection{Spectral analysis}

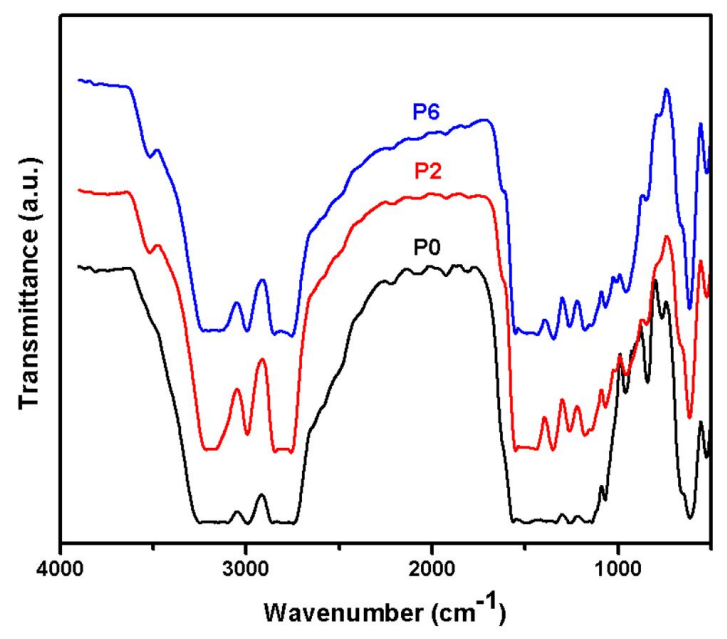

Fig. 2. FT-IR spectra of P0, P2 and P6 membranes.

Fig. 2 shows FT-IR spectra of the polyimide and MMT polymer composite membranes. The characteristic absorption peaks of imide groups are present at around 1711, 1780, and $1342 \mathrm{~cm}^{-1}$. Among them, the peak at $1711 \mathrm{~cm}^{-1}$, representing an imide group, and $1780 \mathrm{~cm}^{-1}$, indicating a cyclic five-membered ring, confirm imide formation. The band at $1342 \mathrm{~cm}^{-1}$ is attributed to the $\mathrm{C}-\mathrm{N}-\mathrm{C}$ bond $[25,27,28]$. It can be seen that in the $3200-3800 \mathrm{~cm}^{-1}$ region, the revealed absorption peaks located at 3689 and $3485 \mathrm{~cm}^{-1}$, respectively, are due to stretching vibrations of hydroxyl groups [29]. In addition, the broad peak at $2260 \mathrm{~cm}^{-1}$, present in all the prepared membranes, is associated with the isocyanate group of PI [30]. The characteristic vibration bands of $\mathrm{Si}-\mathrm{O}-\mathrm{Si}$ bridges from the clay are observed at $477 \mathrm{~cm}^{-1}$ and $1100 \mathrm{~cm}^{-1}$ [31]. FT-IR spectrum of composite films have also shown the characteristic absorption bands of $\mathrm{Si}-\mathrm{O}$ moieties and $\mathrm{Mg}-\mathrm{O}$ moieties at 1035 and at $465 \mathrm{~cm}^{-1}$, respectively [32].
Absorption peak at $3466 \mathrm{~cm}^{-1}$ has been shifted to $3882-3492 \mathrm{~cm}^{-1}$ while adding MMT to the PI matrix. The characteristic bands at $1262 \mathrm{~cm}^{-1}$ and $1300 \mathrm{~cm}^{-1}$ are present in all the membranes except pure PI, suggesting that MMT is successfully incorporated into PI polymer matrix. The characteristic vibration bands of MMT are shown near $1075 \mathrm{~cm}^{-1}$ (Si-O) [33, 34].

\subsection{XRD analysis}

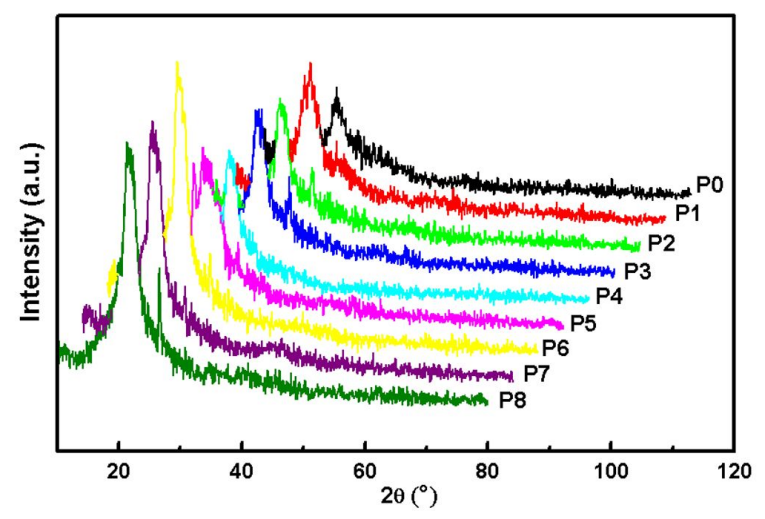

Fig. 3. XRD spectra of the composite membranes.

X-ray diffraction patterns of the PI and their composite membranes are shown in Fig. 3. A diffraction peak, observed around $2 \theta=21^{\circ}$ for all the prepared membranes, is indicative of a semicrystalline structure $[31,35]$. As the loading of MMT nanoclay particles into the polymer network increases, the corresponding semi-crystalline peak intensity increases and it becomes broadened in the membranes containing 5 wt.\% and 10 wt.\% MMT but in the membranes containing 15 wt.\% and 20 wt.\% MMT, it remains sharp. This suggests that the membranes with low content of MMT filler interact well with the polymer matrix. Asgari et al. [36] reported that the nanoparticles dispersion in the polymer solution is affected by the rate of stirring and concentration of nanoparticles. These two factors may have also played a role in the present study. It is clearly observed that the rate of stirring is slowing down with increasing concentration of MMT in the PI polymeric solution, which may lead to 
agglomerations. Further, the formation of agglomerations in the composite PEM is due to variation in the rate of stirring at the concentration from 5 wt. $\%$ to 20 wt. $\%$. It can be noticed that, the constant rate of stirring is maintained up to $10 \mathrm{wt} . \%$ of MMT, later it decreases due to increasing level of MMT during membrane preparation. However, the non-uniform and regular shape of the polymer membrane indicates the non-homogeneous mixing of polymer and clay minerals. The existence of amorphous phase may support the proton transport through the membrane.

\subsection{Morphology}

SEM micrograph of membrane P6 at magnification of $\times 20000$ is shown in Fig. 4. The dark areas in the figure represent the PI matrix and the white parts are the MMT layers. The randomly dispersed needle like-silicate structures are estimated to be $\sim 90 \mathrm{~nm}$ in thickness and $0.5-4 \mu \mathrm{m}$ in length. Moreover, exfoliation of nanoclay particles may have occurred and is visible as the white-blurred regions in the micrograph [37]. The morphology of the membrane has not changed a lot, and no aggregation of clay particles has been observed in the membrane. The same results have been reflected in the XRD studies.

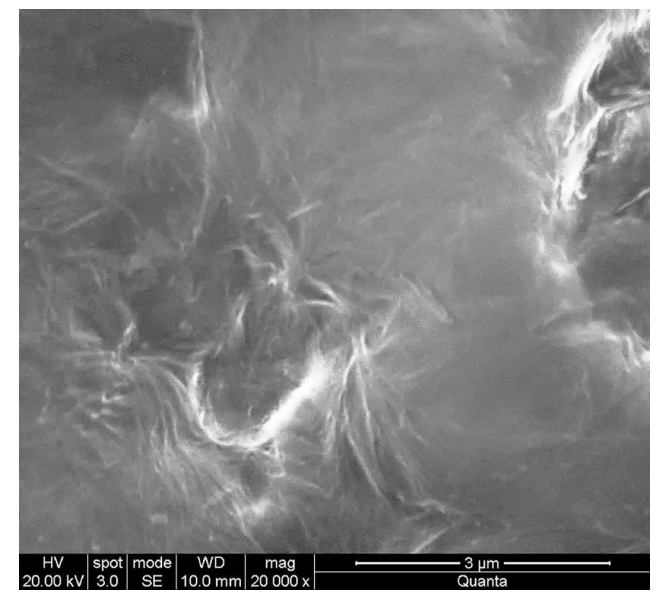

Fig. 4. SEM micrograph of P6 membrane.

\subsection{Ion exchange capacity (IEC)}

Fig. 5 shows the variation of IEC values as a funtion of additive (MMT) concentration.
The graph indicates the number of exchangeable proton sites within the membrane as well as the proton conducting ability of the membrane. Generally, a polymer membrane with higher IEC tends to have higher water uptake capacity [38, 39]. Due to addition of MMT, all the membranes showed higher IEC values than that of pure PI membrane, which indicates a clear proton exchange process. More ion exchangeable sites, caused by the existence of amine and hydroxyl groups, are present in the composite membrane P6, as it shows higher IEC value $\left(2.14 \mathrm{meq} \cdot \mathrm{g}^{-1}\right)$ than the others.

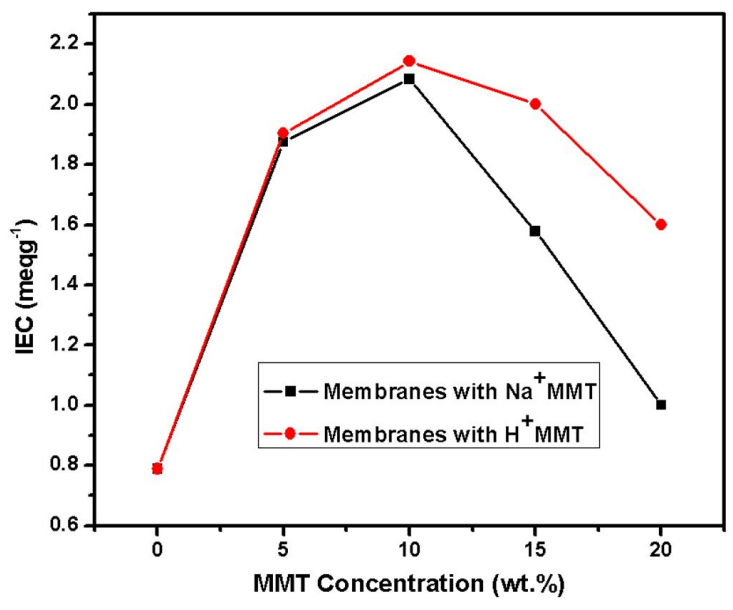

Fig. 5. Variation in IEC values of the composite membranes as a function of MMT concentration.

\subsection{Water uptake, methanol uptake}

Ionic group content in the polyimide chain may help to increase its water uptake ability. However, this may result in higher swelling of membrane which leads to a loss of its mechanical stability and to high methanol permeability. Hence, optimization of water uptake and polymer swelling is required for the successful operation of fuel cells [40]. Physically adsorbed water acts as a proton-carrying medium that follows vehicle mechanism, while chemically adsorbed water obeys Grotthuss mechanism by establishing hydrogen bonds [41]. The water uptake and methanol uptake values of the composite PI membranes with various amounts of MMT are listed in Table 2 and are shown in Fig. 6 and Fig. 7, respectively. While 
Table 2. Ion exchange capacity, water uptake, dimensional change and methanol uptake of polymer electrolyte membranes.

\begin{tabular}{cccccc}
\hline \multirow{2}{*}{ Membrane } & \multirow{2}{*}{ IEC $\left[\mathrm{meq} \cdot \mathrm{g}^{-1}\right.$ ] } & \multirow{2}{*}{ Water uptake [\%] } & \multirow{2}{*}{ Swelling [\%] } & \multicolumn{2}{c}{ Methanol uptake [\%] } \\
\cline { 5 - 6 } & & & & & \\
3 vol.\% & 5 vol.\% \\
\hline \hline P0 & 0.79 & 5.71 & 0.26 & 33.33 & 40.00 \\
P1 & 1.88 & 10.00 & 0.02 & 33.33 & 16.67 \\
P2 & 2.08 & 13.04 & 0.10 & 20.00 & 12.50 \\
P3 & 1.58 & 8.57 & 0.23 & 50.00 & 25.00 \\
P4 & 1.00 & 7.69 & 0.30 & 75.00 & 33.33 \\
P5 & 1.90 & 10.53 & 0.13 & 25.00 & 16.67 \\
P6 & 2.14 & 15.79 & 0.18 & 20.00 & 14.29 \\
P7 & 2.00 & 10.00 & 0.29 & 33.33 & 16.67 \\
P8 & 1.60 & 9.30 & 0.33 & 50.00 & 20.00 \\
\hline
\end{tabular}

comparing the uptake values, PEMs modified with MMT have higher water uptake than the unmodified ones, which is due to high amount of $\mathrm{H}^{+}$ions. Methanol uptake (3 vol.\%, 5 vol.\%) measurement was carried out under the same procedure. Among the various membranes, membrane P6 has the highest water uptake and the lowest methanol uptake value.

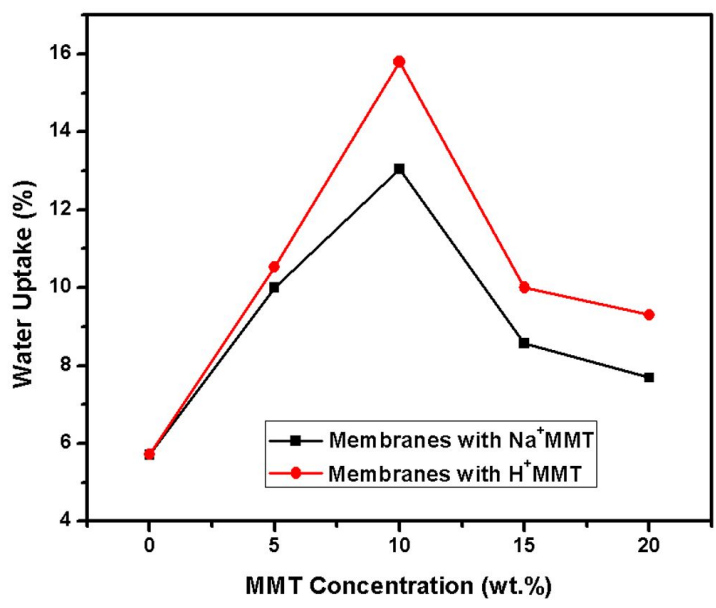

Fig. 6. Variation of water uptake of the composite membranes as a function of MMT concentration.

\subsection{Swelling}

A large dimensional change was exhibited by the PI composite membranes in the thickness direction because the rigid polymer backbone together

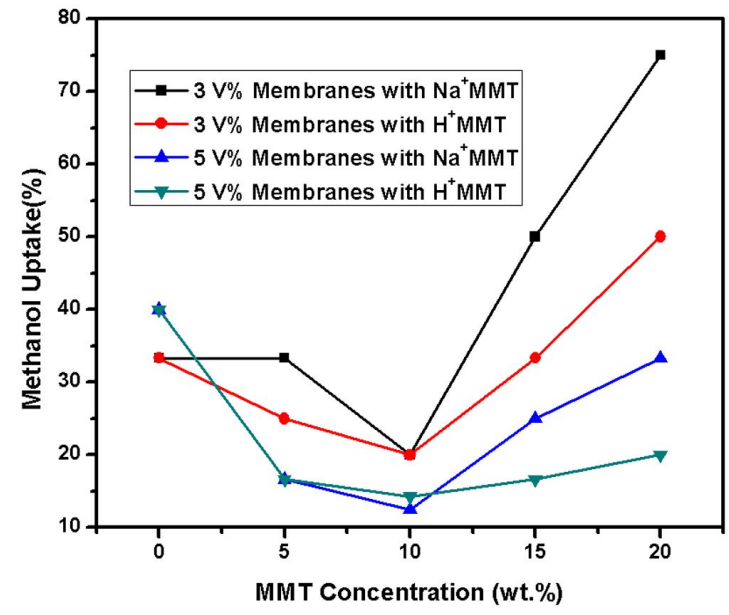

Fig. 7. Variation of methanol uptake of the composite membranes as a function of MMT concentration.

with strong interchain interactions led to the alignment of the polymer backbone in the plane direction [42]. Table 2 compares the anisotropic dimensional change (i.e. thickness-based dimensional expansion) of the composite membranes as well as pure PI membrane. Variation in swelling of PI composite membranes as a function of MMT concentration is shown in Fig. 8. The lower concentration of MMT in the polymer membrane lowers its swelling percentage. But in the case of high concentration of MMT in the polymer membrane, swelling percentage increases gradually. This can be attributed to the presence of MMT, which may 


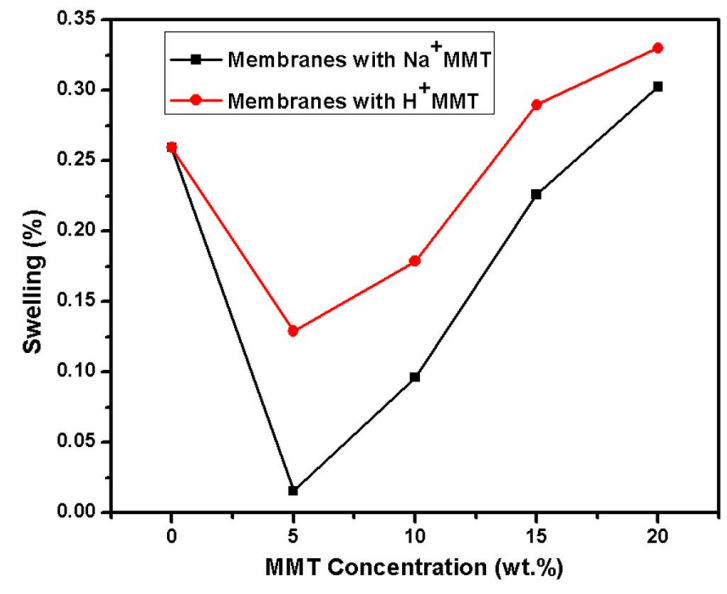

Fig. 8. Variation in swelling of PI composite membranes as a function of MMT concentration.

promote the swelling of the composite membrane. This swelling behavior plays a remarkable role in mass transfer, ion exchange and ionic interaction.

\subsection{Thermal analysis}

TGA results reveal the thermal stability of the PEM material to be used in electrochemical applications. The TGA results and the first order derivative of the TGA (DTG) are demonstrated in Fig. 9 and Fig. 10, respectively and they are listed in Table 3. Two steps of thermal degradation are observed in the pure PI membrane; the first step appears in the range of $90{ }^{\circ} \mathrm{C}$ to $180{ }^{\circ} \mathrm{C}$. The weight loss in this region is about $4-6 \%$ which may be attributed to the loss of residual solvents and water molecules $[26,43]$. The second weight loss region ranges from $350{ }^{\circ} \mathrm{C}$ to $500{ }^{\circ} \mathrm{C}$ and the weight loss in this region is about $84-88 \%$. It is attributed to the decomposition of imide functional groups from the polyimide matrix [44]. Similar trends were observed in all prepared PI/MMT (modified /unmodified) composite membranes.

The first order derivative of TG curve shows two thermal degradation peaks which correspond to the weight loss region of the TGA thermograms. It is noticed that the major thermal degradation peaks for all the composite membranes are shifted towards lower temperature as compared to the pure PI except the sample P1. On the other hand, the rate of thermal degradation for the pure PI membrane is $1.033 \mathrm{mg} \cdot \mathrm{min}^{-1}$. The thermal degradation rates of the membranes with unmodified MMT, ranging from $2.481 \mathrm{mg} \cdot \mathrm{min}^{-1}$ to $1.389 \mathrm{mg} \cdot \mathrm{min}^{-1}$, and $\mathrm{mod}-$ ified MMT, ranging from $1.317 \mathrm{mg} \cdot \mathrm{min}^{-1}$ to $1.008 \mathrm{mg} \cdot \mathrm{min}^{-1}$, have been reduced while increasing the MMT concentration in the PI polymer matrix.

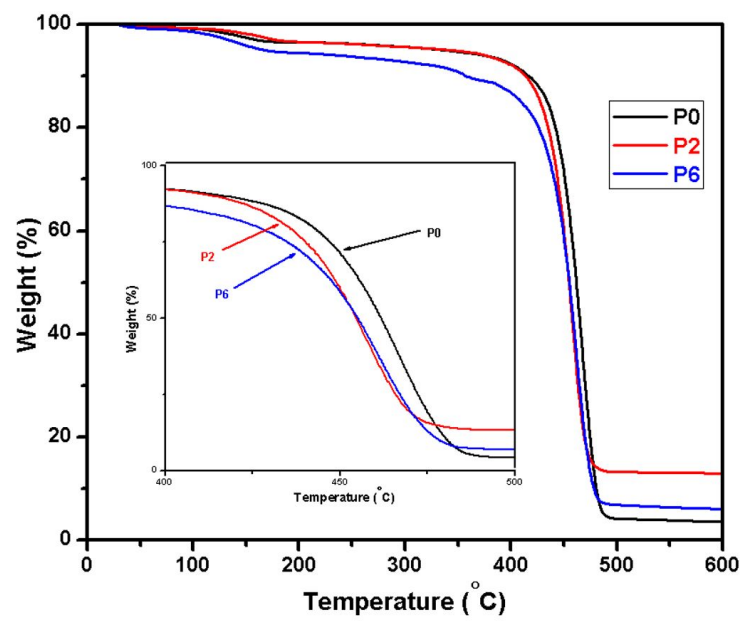

Fig. 9. TGA curves of P0, P2 and P6 membranes.

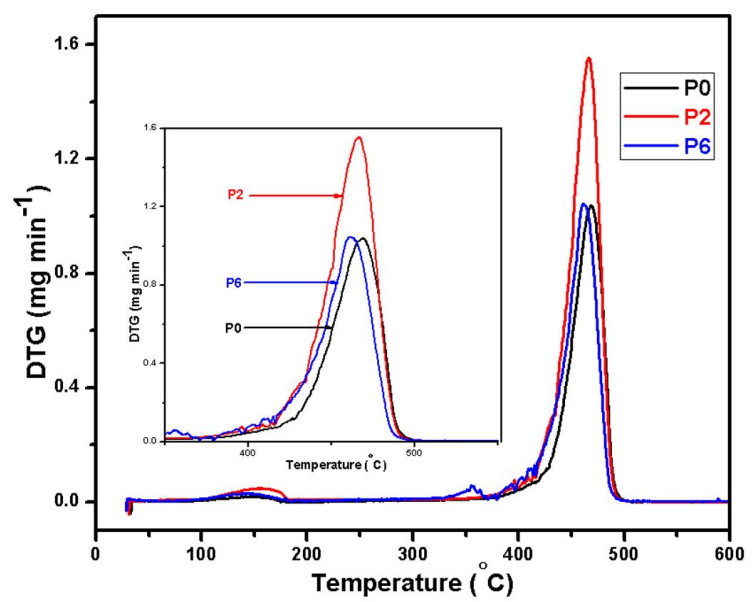

Fig. 10. DTG curves of P0, P2 and P6 membranes.

\subsection{Conductivity}

Proton conductivity measurements were performed using $\mathrm{CH}$ Instruments Electrochemical Analyzer in the frequency range of $1 \mathrm{KHz}$ to $10 \mathrm{MHz}$, 
Table 3. Results of TGA thermograms for the different of membranes.

\begin{tabular}{cccccccc}
\hline & \multicolumn{7}{c}{ TGA } \\
\cline { 2 - 7 } Membrane & $\begin{array}{c}1^{\text {st }} \text { step } \\
{\left[{ }^{\circ} \mathrm{C}\right]}\end{array}$ & $\begin{array}{c}\text { Weight } \\
\text { loss [wt.\% }]\end{array}$ & $\begin{array}{c}2^{\text {nd }} \text { step } \\
{\left[{ }^{\circ} \mathrm{C}\right]}\end{array}$ & $\begin{array}{c}\text { Weight } \\
\text { loss } \\
{[\mathrm{wt} . \%]}\end{array}$ & $\begin{array}{c}\text { Char yield } \\
\text { at } 500{ }^{\circ} \mathrm{C} \\
{[\mathrm{wt} . \%]}\end{array}$ & $\begin{array}{c}\text { Major thermal } \\
\text { degradation peak } \\
\text { position }\left[{ }^{\circ} \mathrm{C}\right]\end{array}$ & $\begin{array}{c}\text { Rate of } \\
\text { degradation } \\
{\left[\mathrm{mg} \cdot \mathrm{min}^{-1} \text { ] }\right.}\end{array}$ \\
\hline \hline P0 & $90-180$ & $4-6$ & $350-500$ & $84-88$ & 4.2 & 468 & 1.033 \\
P1 & $100-180$ & $2-4$ & $350-490$ & $84-88$ & 4.96 & 474 & 2.481 \\
P2 & $100-180$ & $2-4$ & $350-480$ & $85-89$ & 5.52 & 460 & 1.990 \\
P3 & $110-190$ & $2-4$ & $350-480$ & $80-84$ & 13.23 & 466 & 1.547 \\
P4 & $100-180$ & $2-4$ & $360-490$ & $70-74$ & 20.64 & 464 & 1.389 \\
P5 & $115-190$ & $2-4$ & $390-490$ & $85-88$ & 2.52 & 466 & 1.317 \\
P6 & $105-180$ & $4-8$ & $380-480$ & $80-83$ & 6.62 & 435 & 1.138 \\
P7 & $110-190$ & $2-4$ & $350-480$ & $72-75$ & 15.23 & 462 & 1.036 \\
P8 & $100-180$ & $4-6$ & $350-470$ & $68-72$ & 20.79 & 453 & 1.008 \\
\hline
\end{tabular}

at $30{ }^{\circ} \mathrm{C}, 40{ }^{\circ} \mathrm{C}, 50{ }^{\circ} \mathrm{C}, 60{ }^{\circ} \mathrm{C}$ and $70{ }^{\circ} \mathrm{C}$ and are listed in Table 4. Fig. 11 illustrates variation in proton conductivities as a function of MMT concentration at varying temperatures.

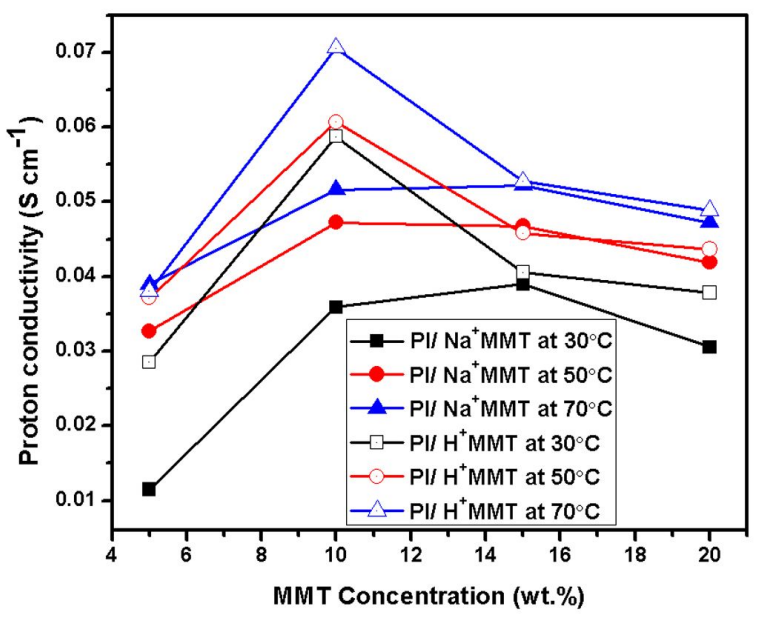

Fig. 11. Variation of proton conductivity as a function of MMT concentration.

It is observed that when the additive concentration in PI increases, the proton conductivity values increase up to $10 \mathrm{wt} . \%$ of MMT and then decrease. It may due to agglomeration of MMT filler during the membrane preparation, which is confirmed by the results of XRD studies. Also, the membranes with modified MMT show higher proton conductivities than unmodified MMT due to the

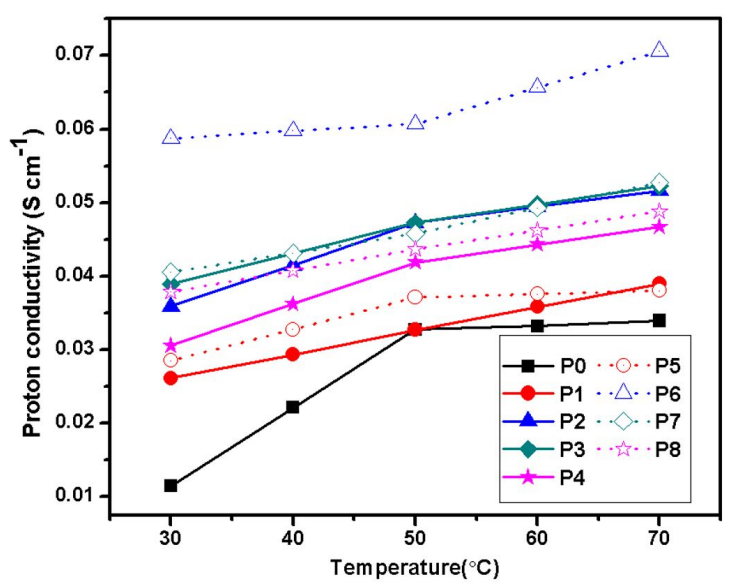

Fig. 12. Proton conductivity of membranes as a function of temperature.

hopping of protons. Here, the proton transport is facilitated through the Grotthuss mechanism, which originates due to the generation of a continuous proton conductive pathway. The high proton conductivity of membrane P6 is $7.06 \times 10^{-2} \mathrm{~S} \cdot \mathrm{cm}^{-1}$. Fig. 12 illustrates the dependence of the membrane conductivity as a function of temperature. It is observed that when the temperature increases, the proton conductivity values also increase and follow the Arrhenius relationship. The increase in temperature favors both the dynamics involved in proton transfer and structural reorganization, which are required for fast proton conductivity. 
Table 4. Proton conductivity $(\sigma)$ and activation energy $\left(\mathrm{E}_{a}\right)$ of membranes.

\begin{tabular}{ccccccc}
\hline Membrane & \multicolumn{5}{c}{ Proton conductivity $\left[\mathrm{S} \cdot \mathrm{cm}^{-1}\right]$} & \multicolumn{2}{c}{ Activation energy $\mathrm{E}_{\mathrm{a}}\left[\mathrm{kJ} \cdot \mathrm{mol}^{-1}\right]$} \\
& $30\left[{ }^{\circ} \mathrm{C}\right]$ & $40\left[{ }^{\circ} \mathrm{C}\right]$ & $50\left[{ }^{\circ} \mathrm{C}\right]$ & $60\left[{ }^{\circ} \mathrm{C}\right]$ & $70\left[{ }^{\circ} \mathrm{C}\right]$ & 9.83 \\
\hline \hline P0 & 0.011 & 0.022 & 0.033 & 0.033 & 0.034 & 3.76 \\
P1 & 0.026 & 0.029 & 0.033 & 0.036 & 0.039 & 3.42 \\
P2 & 0.036 & 0.042 & 0.047 & 0.049 & 0.052 & 2.76 \\
P3 & 0.039 & 0.043 & 0.047 & 0.050 & 0.052 & 3.97 \\
P4 & 0.031 & 0.036 & 0.042 & 0.044 & 0.047 & 2.71 \\
P5 & 0.029 & 0.033 & 0.037 & 0.038 & 0.038 & 1.71 \\
P6 & 0.059 & 0.060 & 0.061 & 0.066 & 0.071 & 2.46 \\
P7 & 0.041 & 0.043 & 0.046 & 0.049 & 0.053 & 2.38 \\
P8 & 0.038 & 0.041 & 0.044 & 0.046 & 0.049 & \\
\hline
\end{tabular}

\section{Conclusions}

The effects of MMT content on polyimide ion exchange capacity, water uptake, methanol uptake, proton conductivity were studied at temperatures $30{ }^{\circ} \mathrm{C}, 40{ }^{\circ} \mathrm{C}, 50{ }^{\circ} \mathrm{C}, 60{ }^{\circ} \mathrm{C}$ and $70{ }^{\circ} \mathrm{C}$. Relatively high proton conductivity values were achieved and it was shown that they were dependent on ion exchange capacity and temperature. At $70{ }^{\circ} \mathrm{C}$, the membranes with high IEC values showed higher proton conductivities at $100 \%$ relative humidity level, due to their lower activation energies, indicating potential application for direct methanol fuel cells. The introduction of MMT into the polymer network may have assisted in the proton transfer mechanism. At $70{ }^{\circ} \mathrm{C}$, the proton conductivity of the P6 membrane was $7.1 \times 10^{-2} \mathrm{~S} \cdot \mathrm{cm}^{-1}$, which exceeds the previously reported values of several other PI composite membranes [45-47]. Since the membrane P6 showed the best results in water uptake, swelling ratio and proton conductivity among the studied composites, it is expected that this composite membrane will deliver excellent performance in fuel cell systems in nearest future.

\section{Acknowledgements}

Our sincere gratitude to the Department of Science and Technology of India for supporting this work, through the Science Engineering Research Board (DST-SERB) Program.

\section{References}

[1] Cruz J.C., Baglio V., Siracusano S., OrNelas R., Arriaga L.G., Antonucci V., Arico A.S., Int. J. Hydrogen Energ., 37 (2012), 5508.
[2] Kim J., LeE I., TAK Y., CHO B.H., Int. J. Hydrogen Energ., 37 (2012), 4280.

[3] Chen P.C., Int. J. Hydrogen Energ., 36 (2011), 14608.

[4] LiYanage A.D., FerRaris J.P., Musselman I.H., YANG D.-J., ANDERSSON T.E., DAVID Y. SON D.Y., BALKUS K.B. JR. J., J. Membrane Sci., 392 - 393 (2012), 175.

[5] Geng L., He Y., LiU D., Dai X., LU C., Micropor. Mesopor. Mat., 148 (2012), 8.

[6] Seo J., Jang W., Lee S., Han H., Polym. Degrad. Stabil., 93 (2008), 298.

[7] Miyatake K., Furuya H., TAnaka M., WatanABE M., J. Power Sources, 204 (2012), 74.

[8] Song J.M., Miyatake K., Uchida H., WatanABE M., Electrochim. Acta, 51 (2006), 4497.

[9] PU H.-T., QIAO L., LiU Q.-Z., YANG Z.-L., Eur. Polym. J., 41 (2005), 2505.

[10] Liaw D.-J., WANG K.-L., HuAng Y.-C., LEE K.-R., Lai J.-Y., Ha C.-S., Prog. Polym. Sci., 37 (2012), 907.

[11] OKAMOTO K.-I., YIN Y., YAMADA O., ISLAM N.M., Honda T., Mishima T., Suto Y., TANaKa K., KITA H., J. Membrane Sci., 258 (2005), 115.

[12] Jang W., Lee C., Sundar S., Shul Y.G., Han H., Polym. Degrad. Stabil., 90 (2005), 431.

[13] Rehman S.-U., Li P., Zhou H., Zhao X., Dang G., Chen C., Polym. Degrad. Stabil., 97 (2012), 1581.

[14] PU H., WANG D., Electrochim. Acta, 51 (2006), 5612.

[15] Pan H., Zhang Y., PU H., Chang Z., J. Power Sources, 263 (2014), 195.

[16] Lin L., Zhang C., LiU C., Dong M., Zhang L., Deng P., Sun H., Huang H., Liu H., Zhang Y., Int. J. Hydrogen Energ., 39 (2014), 4704.

[17] Nguyen T.H., Wang C., Wang X., J. Membrane Sci., 342 (2009), 208.

[18] Liu J., Zhang Q., Xia Q., Dong J., Xu Q., Polym. Degrad. Stabil., 97 (2012), 987.

[19] HASANI-SADRABADI M.M., GhaFFARIAN S.R., MOKARRAM-Dorri N., DAShtimoghadaM E., FATEMEH S.M., Solid State Ionics, 180 (2009), 1497. 
[20] Palani B.P., Abidin S.K., Kannan R., SivaKuMar M., Ming F.W., Rajashabala S., Velraj G., RSC Adv., 4 (2014), 61781.

[21] Wang T., Sun F., Wang H., Yang S., Fan L., Polymer, 53 (2012), 3154.

[22] Yang T., LiU C., Int. J. Hydrogen Energ., 36 (2011), 5666.

[23] YANG T., Int. J. Hydrogen Energ., 34 (2009), 6917.

[24] Bai H., Ho W.S.W., J. Membrane Sci., 313 (2008), 75.

[25] Petrou A.L., Roulia M., Tampouris K., Chem. Educ. Res. Pract., 3 (2002), 87.

[26] Gong C., Liang Y., Qi Z., Li H., Wu Z., Zhang Z., Zhang S., Zhang X., LI Y., J. Membrane Sci., 476 (2015), 364.

[27] Yang Y., Yin D., Xiong R., Shi J., Tian F., WANG X., LEI Q., IEEE T. Dielect. El. In., 19 (2012), 574.

[28] Lee T., Park S.S., Jung Y., HaN S., HaN D., KIM I., HA C.-S., Eur. Polym. J., 45 (2009), 19.

[29] Yu Y., Qi S., Zhan J., Wu Z., Yang X., Wu D., Mater. Res. Bull., 46 (2011), 1593.

[30] Chao T.-Y., Chang H.-L., Su W.-C., Wu J.-Y., JENG R.-J., Dyes Pigments, 77 (2008), 515.

[31] Ahmad M.B., Gharayebi Y., Salit S.M., HusSEIN Z.M., Ebrahimiasl S., Dehzangi A., Int. J. Mol. Sci., 13 (2012), 4860.

[32] Faghini K., Taher M., Hajibeygi M., Arab. J. Chem., 9 (2016), 1496.

[33] Faghini K., Ashouri M., Feyzi A., J. Mex. Chem. Soc., 57 (2013), 133.

[34] Zhang C., Zhang M., CAO H., Zhang Z., Wang Z., Gao L., Ding M., Compos. Sci. Technol., 67 (2007), 380.

[35] DhaKShNamoorthy M., VikRAM S., VASANTHAKUMARI R., Int. J. Sci. Eng. Res., 3 (2012), 1.
[36] Asgari M., Aliofkhazraei M., Barati D.G., Rouhaghdam S.A., Surf. Coat. Technol., 309 (2015), 124.

[37] Liliane C.B., Luiz H.S.G., Ubirajara P.R., GerMANO T., Membranes 2 (2012), 430.

[38] Watari T., FANG J., TANAKA K., KitA H., OKamoto K.-I., Hirano T., J. Membrane Sci., 230 (2004), 111.

[39] Einsla B.R., Kim Y.S., Hickner M.A., Hong Y.T., Hill M.L., Pivovar B.S., Mcgrath J.E., $J$. Membrane Sci., 255 (2005), 141.

[40] JANG W., Sundar S., ChOI S., Shul Y.-G., HAN H., J. Membrane Sci., 280 (2006), 321.

[41] LeE J.-R., Kim N.-Y., LEE M.-S., LeE S.-Y., J. Membrane Sci., 367 (2011), 265.

[42] SU Y.-H., LIU Y.-L., SUN Y.-M., LAI J.-Y., WANG D.-M., Gao Y., LiU B., Guiver M.D., J. Membrane Sci., 296 (2007), 21.

[43] Chatzidaki E.K., Favvas E.P., Papageorgiou S.K., KANellopoulos N.K., Theophilou N.V., Eur. Polym. J., 43 (2007), 5010.

[44] Zhang L.-B., Wang J.-Q., Wang H.-G., XU Y., WANG Z.-F., Li Z.-P., Mi Y.-J., YANG S.-R., Compos. Part A-Appl. S., 43 (2012), 1537.

[45] Pan H., Chen S., Zhang Y., Jin M., Chang Z., Pu H., J. Membrane Sci., 476 (2015), 87.

[46] Nguyen T., Wang X., J. Power Sources, 195 (2010), 1024.

[47] Li W., Shen C., Gao S., Yin S., Li H., Solid State Ionics, 287 (2016), 1.

Received 2016-09-26

Accepted 2017-12-15 